

\title{
Identyfikacja molekularnej przyczyny epizodycznie postępującego niedosłuchu u pacjentki z poszerzonym wodociągiem przedsionka i dysplazją środkowo-szczytowych odcinków ślimaka
}

\section{Identification of the molecular cause of episodic progressive hearing loss in a patient with enlarged vestibular aqueduct and dysplasia of mid-peak section of the cochlea}

\author{
Agnieszka Pollak ${ }^{1 A B D E F G}$, Urszula Lechowicz ${ }^{1 B D E F}$, Henryk Skarżyński ${ }^{2 D E G}$, \\ Rafał Płoski $^{3 A D E}$, Monika Ołdak ${ }^{1 B D E F}$ \\ ${ }^{1}$ Instytut Fizjologii i Patologii Słuchu, Światowe Centrum Słuchu, Zakład Genetyki, \\ Warszawa/Kajetany \\ ${ }^{2}$ Instytut Fizjologii i Patologii Słuchu, Światowe Centrum Słuchu, Klinika Oto-Ryno- \\ Laryngochirurgii, Warszawa/Kajetany \\ ${ }^{3}$ Warszawski Uniwersytet Medyczny, Zakład Genetyki Medycznej, Warszawa
}

\section{Streszczenie}

Uważa się, że w proces percepcji bodźców słuchowych zaangażowanych jest kilkaset produktów różnych genów, a patogenne warianty w każdym z nich mogą być odpowiedzialne za wystąpienie ubytku słuchu. Tak więc niedosłuch to wysoce zróżnicowane pod względem genetycznym schorzenie, a ustalenie jego przyczyny w wielu przypadkach jest wyzwaniem. Wprowadzenie nowoczesnych technologii sekwencjonowania nowej generacji umożliwiło wykonywanie analiz wielogenowych również w badaniu podłoża genetycznego niedosłuchu. Celem pracy była identyfikacja molekularnego podłoża epizodycznie postępującego niedosłuchu u pacjentki z poszerzonym wodociągiem przedsionka i dysplazją środkowo-szczytowych odcinków ślimaka. U pacjentki wykonano sekwencjonowanie całoeksomowe i wykryto dwa warianty sprawcze w genie SLC26A4, tym samym identyfikując molekularną przyczynę opisywanych objawów. Słowa kluczowe: $S L C 26 A 4 \bullet$ poszerzony wodociąg przedsionka • EVA • sekwencjonowanie nowej generacji

\begin{abstract} by identifying the molecular cause of the described symptoms and signs.

Key words: $S L C 26 A 4 \bullet$ enlarged vestibular aqueduct $\bullet$ EVA $\bullet$ next generation sequencing

It is believed that several hundred products of different genes are involved in the process of sound perception, and pathogenic variants in every one of them can be responsible for hearing loss. Thus, hearing loss presents itself as a genetically highly differentiated disorder, and in many cases it is a challenge to establish its cause. Introduction of next generation sequencing made it possible to perform multigene analyzes to detect the genetic background of hearing loss. The aim of the study was to identify the molecular basis of episodic progressive hearing loss in a patient with an enlarged vestibular aqueduct and dysplasia of the central-peak sections of the cochlea. The patient underwent whole exome sequencing and two causative variants were identified in the SLC26A4 gene, there- 


\section{Wstęp}

Statystyki Światowej Organizacji Zdrowia (WHO) dowodzą, że na znaczące zaburzenia słyszenia uskarża się 360 mln osób na całym świecie, a lżejsze formy tego schorzenia, mające wpływ na codzienne komunikowanie się, mogą dotyczyć nawet 1 mld ludzi. Tym samym niedosłuch stanowi najczęstszą wadę narządów zmysłów u człowieka. Uważa się, że 1-2 na 1000 dzieci rodzi się z niedosłuchem [1], a czynniki genetyczne są odpowiedzialne za większość (ponad 80\%) przypadków niedosłuchu wrodzonego oraz około 50\% niedosłuchu ujawniającego się w wieku późniejszym [2]. Szacuje się, że około 30\% przypadków dziedzicznej postaci uszkodzenia słuchu, stanowią chorzy, u których niedosłuch jest tylko jednym z objawów współistniejących z zespołem wad lub cech dysmorficznych [3]. Opisano do tej pory około 400 takich zespołów [4], a jednym $\mathrm{z}$ nich jest zespół Pendreda (PDS, MIM\#274600). Częstość występowania PDS szacowana jest na 7,5-10 na 100000 osób i odpowiada za ok. 10\% przypadków niedosłuchów wrodzonych $[5,6]$. Choroba dziedziczy się w sposób autosomalny recesywny i jest wywołana uszkodzeniem genu SLC26A4 (MIM \#605646), znajdującego się w locus 7q22.3-7q31.1 [7]. Gen SLC26A4 ulega ekspresji w tarczycy, nerkach oraz uchu wewnętrznym [8-12], zbudowany jest z 21 eksonów kodujących białko - pendrynę, składające się z 780 aminokwasów. W badaniach na modelu mysim wykazano, że pendryna funkcjonuje jako przezbłonowy transporter jonów jodu, chloru oraz wodorowęglanowych i ma bezpośredni wpływ na rozwój ślimaka i funkcji słuchowych. Brak

Rycina 1. Krzywe audiometryczne pacjentki przedstawiające poziom niedosłuchu w 13 r.ż. (górny panel) i 17 r.ż. (dolny panel) Figure 1. Patient's hearing thresholds at 13 y.o.a. (upper panel) and at 17 y.o.a. (lower panel)

PRAWE UCHO

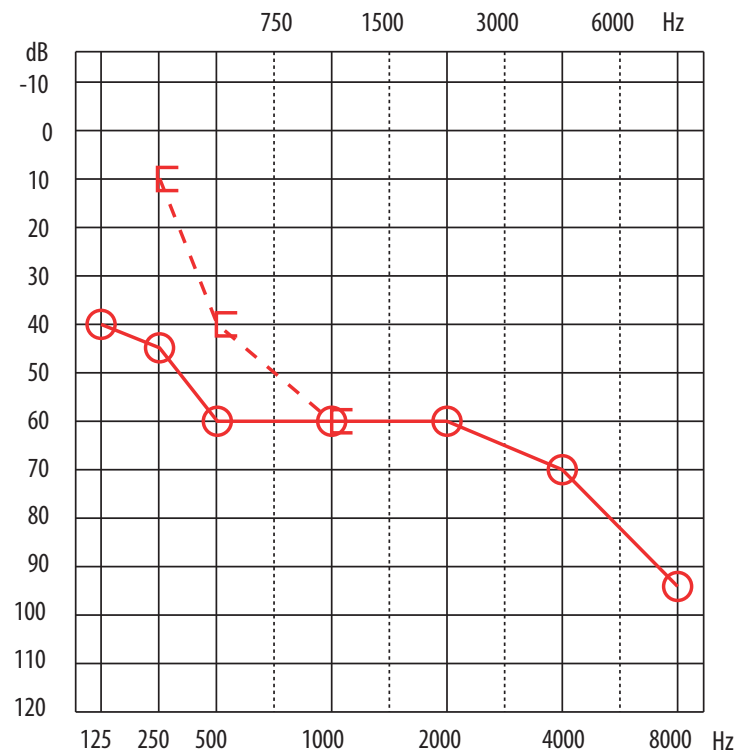

PRAWE UCHO

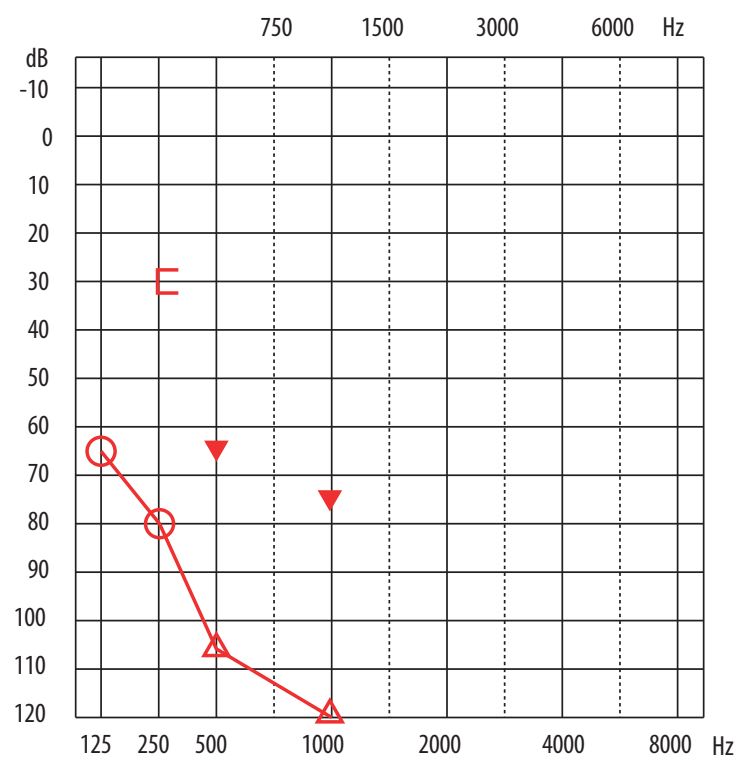

LEWE UCHO



LEWEUCHO

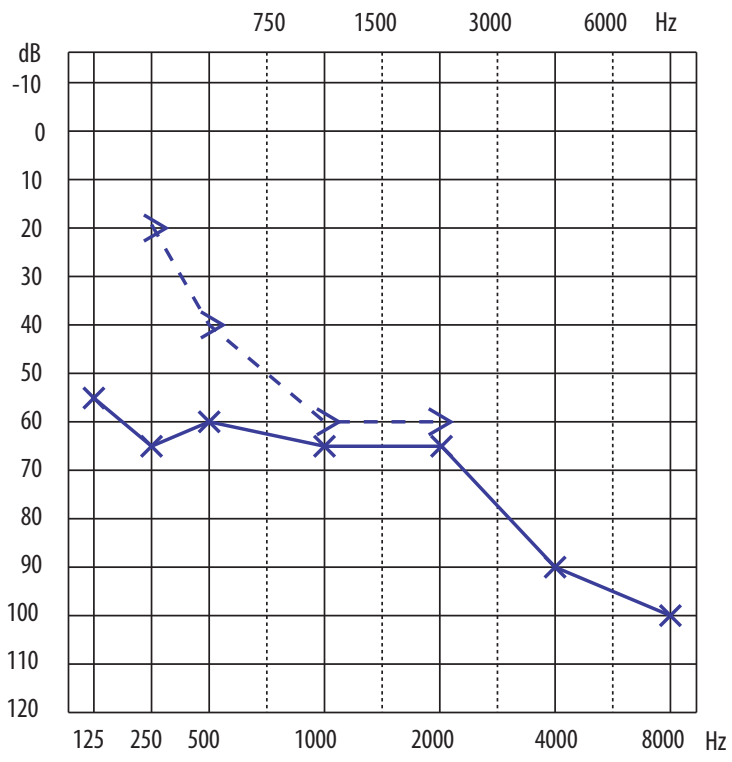


aktywności pendryny w uchu wewnętrznym skutkuje zakwaszeniem endolimfy, a przez to poważnym zaburzeniem równowagi jonowej, która jest szczególnie ważna podczas rozwoju ucha wewnętrznego. Bezpośrednim efektem jest nieprawidłowe formowanie struktur kostnych, takich jak ślimak i wodociąg przedsionka, oraz utrata potencjału wewnątrzślimakowego i niedosłuch $[8,13]$.

PDS charakteryzuje się zwykle wrodzonym głębokim niedosłuchem, występowaniem nieprawidłowości w budowie ucha wewnętrznego (zespół poszerzonego wodociągu przedsionka (ang. enlarged vestibular aqueduct - EVA, i/lub malformacja Mondiniego (MD)) [14,15], w drugiej dekadzie życia u większości pacjentów rozwija się wole, a w $50 \%$ przypadków pojawia się niedoczynność tarczycy. Wodociąg przedsionka definiowany jest jako poszerzony, gdy jego średnica w części środkowej przekracza $1,5 \mathrm{~mm}$ [16], natomiast malformacja Mondiniego (inaczej określana jako niepełny podział typu II - IP2) to dysplazja ślimaka przejawiająca się w zmniejszonej liczbie jego zakrętów $(1-1,5)$ oraz niepełnym rozwoju błon separujących schody ślimaka [17].

Warianty patogenne genu SLC26A4 mogą skutkować wystąpieniem zespołu Pendreda w pełnej, jak opisano powyżej, postaci, ale również przejawiają się w postaciach poronnych. Warianty patogenne genu SLC26A4 identyfikowane są u osób, u których nie stwierdza się żadnej patologii tarczycy [18]. Mogą one prowadzić do wystąpienia niedosłuchu DFNB4 połączonego z anomaliami w obrębie ucha wewnętrznego (EVA lub EVA/MD) bez komponenty tarczycowej.

Do tej pory opisano 539 różnych wariantów patogennych zlokalizowanych we wszystkich reginach kodujących genu SLC26A4, w obszarach odpowiedzialnych za prawidłowe składanie transkryptów oraz dużych delecji (HGMD Professional 2018.1). W rodzinach z zespołem Pendreda wykrywalność wariantów patogennych sięga prawie 50\% [19], natomiast w nielicznych jak do tej pory publikacjach dotyczących analizy wariantów patogennych genu SLAC26A4 wśród pacjentów z niedosłuchem i malformacjami w obrębie ucha wewnętrznego odsetek ten jest znacznie niższy
[20]. Co interesujące, spektrum wariantów patogennych genu SLC26A4 jest ściśle powiązane z pochodzeniem etnicznym. W populacjach kaukaskich najczęściej wykrywane są warianty c.1001+1G>A, p.Val138Phe, p.Thr416Pro, p.Leu236Pro i p.Gly209Val [21]. Jak dotąd nie prowadzono w Polsce badań dotyczących udziału genu SLC26A4 w patogenezie niedosłuchu izolowanego jak również niedosłuchu z towarzyszącymi malformacjami w obrębie ucha wewnętrznego (poszerzenie wodociągu przedsionka).

\section{Materiał i metody}

Pacjentka (2 lata i 8/12) zgłosiła się do Poradni Genetycznej Instytutu Fizjologii i Patologii Słuchu w celu ustalenia podłoża niedosłuchu. U pacjentki zdiagnozowano mieszany, obustronny ubytek słuchu w stopniu umiarkowanym. W kolejnych latach pacjentka doświadczyła czterech udokumentowanych epizodów nagłej głuchoty, które spowodowały znaczące pogorszenie słuchu w uchu prawym (rycina 1). Pierwotnie jako metodę leczenia/rehabilitacji narządu słuchu zastosowano aparaty słuchowe. Od roku 2017 jest użytkowniczką implantu ślimakowego ConcertoForm24, wszczepionego do prawego ucha. W badaniu przedmiotowym u pacjentki stwierdzono dyskretne cechy dysmorfii w postaci małych małżowin usznych (-1,5 SD dla normy długości i -2 SD dla normy szerokości [22]), wąskie przewody słuchowe oraz obniżoną siłę mięśniową. Badania laboratoryjne wykazały podwyższony poziom kwasu mlekowego. Poziom hormonów tarczycy był w normie. Szczegółowy obraz kliniczny pacjentki przedstawiono w pracy Olszewski i wsp. [23]. U siostry pacjentki w 5 roku życia również zdiagnozowano mieszany niedosłuch w stopniu umiarkowanym (UP) i lekkim (UL). Ponadto stwierdzono - analogicznie - dyskretne cechy dysmorfii w postaci małych małżowin usznych (-1,5 SD dla normy długości i -2 SD dla normy szerokości [22]), oraz wąskie przewody słuchowe. Od szóstego roku życia jest ona użytkownikiem aparatu słuchowego. W ubiegłym roku doświadczyła pojedynczego epizodu pogorszenia stanu słuchu w uchu prawym z przemijającym szumem usznym. Zastosowano sterydoterapię i antybiotykoterapię. Stanu słuchu powrócił do poziomu sprzed epizodu. Poziom hormonów tarczycy pozostaje w normie. Rodowód badanej rodziny przedstawiono na rycinie 2 .

Rycina 2. Rodowód pacjentki (kółka reprezentują kobiety, kwadraty reprezentują mężczyzn, wypełnione kształty przedstawiają pacjentów z niedosłuchem i poszerzonym wodociągiem przedsionka (EVA)). Strzałka wskazuje probanda. Pod odpowiednimi symbolami umieszczono genotypy osób badanych

Figure 2. Family pedigree (circles represent females and squares represent males, filled symbols indicate affected individuals (hearing loss and enlarged vestibular aqueduct (EVA)). Proband is marked with an arrow. Genotypes are given below the respective symbols




U pacjentki oraz jej siostry wykonano badania obrazowe (tomografię komputerową kości skroniowych oraz rezonans magnetyczny)

DNA pacjentki wyizolowano z leukocytów krwi obwodowej metodą wysalania [24]. W pierwszym etapie badań wykluczono udział locus DFNB1 w patogenezie niedosłuchu [25], oraz obecność wariantów m.1555A > G i m.3243A > G w genomie mitochondrialnym [26,27]. Następnie wykonano sekwencjonowanie całoeksomowe (ang. whole exome sequencing, WES), w celu znalezienia wariantów odpowiedzialnych za wystąpienie niedosłuchu. Do przygotowania bibliotek użyto zestawu TruSeq Exome Enrichment Kit (Illumina), a sekwencjonowanie nowej generacji przeprowadzono na aparacie Illumina HiSeq1500, zgodnie z opublikowaną procedurą [28]. Analizę bioinformatyczną przeprowadzono zgodnie z wytycznymi Broad Institute. Wykryte warianty potwierdzono techniką bezpośredniego sekwencjonowania metodą Sangera. Stosowane w pracy startery projektowano, korzystając z programu Primer3 (v.0.4.0) (http://bioinfo.ut.ee/primer3-0.4.0/). Użyto starterów o następujących sekwencjach: SLC_e2F CGCTTACCGCGTGTCCTC, SLC_e2R CGCTCCGCTTCTCTCTACG, SLC_e4F TGGAACCATTGTAAGTTGAGGA, SLC_e4R GCCAAAACACTTTAAACATGAGC. Zapis wariantów przedstawiono na podstawie sekwencji referencyjnych NM_000441.1 i NP_000432 genu SLC26A4. Przeprowadzono również analizę obecności wariantów patogennych w obrębie całego DNA mitochondrialnego.

Analizę konserwatywności aminokwasów u innych gatunków kręgowców wykonano z użyciem algorytmu Mutation Taster2 [29].

\section{Wyniki}

Wykorzystując nowe możliwości badań, jakie pojawiły się dzięki wprowadzeniu przełomowej technologii sekwencjonowania nowej generacji do diagnostyki niedosłuchu uwarunkowanego genetycznie [30], u pacjentki wykonano sekwencjonowanie WES. Analiza ekspercka wyników WES wykazała obecność dwóch wariantów w obszarze kodującym genu SLC26A4 (NM_000441.1:c.[85G>C];[349C>T] NP_000432:p.[(Glu29Gln)];[(Leu117Phe)]). Warianty c. $85 \mathrm{G}>\mathrm{C}$ oraz c.349C $>\mathrm{T}$ zgodnie $\mathrm{z}$ informacjami $\mathrm{z}$ bazy Human Gene Mutation Database (http://www.hgmd.org/) uznane są za patogenne w modelu recesywnym [15,31] i powiązane $\mathrm{z}$ wystąpieniem niedosłuchu oraz malformacji ucha wewnętrznego (EVA, EVA/MD). Wyżej wymienione warianty zlokalizowane są odpowiednio w drugim i czwartym eksonie genu SLC26A4.

Bezpośrednie sekwencjonowanie tych eksonów metodą Sangera potwierdziło obecność wykrytych wariantów u pacjentki oraz u jej niedosłyszącej siostry. Analiza segregacji wykazała obecność heterozygotycznych wariantów u obojga rodziców badanych pacjentek, tym samym potwierdziła lokalizację wariantów na odrębnych chromosomach (układ in trans) (rycina 2). Obrazy obu wariantów otrzymane w wyniku sekwencjonowania WES (obraz z oprogramowania Integrative Genomics Viewer (IGV)) oraz sekwencjonowania bezpośredniego przedstawiono na rycinie 3. Analiza DNA mitochondrialnego wykazała obecność wariantu m.961T $>\mathrm{G}$ w postaci homoplazmatycznej.

Badania obrazowe ujawniły obustronną malformację ślimaka ze spektrum IP2 - poszerzony wodociąg przedsionka (EVA) oraz dysplazję środkowo-szczytowych odcinków ślimaka (rycina 4). U siostry pacjentki w badaniach obrazowych również odnotowano malformacje ze spektrum IP2 - EVA oraz hipoplazję wrzecionka.

\section{Dyskusja}

Patogenne warianty w genie SLC26A4 są uważane za trzecią co do częstości występowania przyczynę niedosłuchu

Rycina 3. Obraz patogennych wariantów genu SLC26A4 c.85G>C (p.Glu29Gln) i c.349C>T (p.Leu117Phe) z oprogramowania Integrative Genomics Viewer (IGV) (lewy panel) oraz sekwencjonowania metodą Sangera (prawy panel)

Figure 3. Picture of the pathogenic variants c.85G>C (p.Glu29Gln) and c.349C>T (p.Leu117Phe) of the SLC26A4 gene from Integrative Genomics Viewer (IGV) (left panel) and Sanger sequencing (right panel)
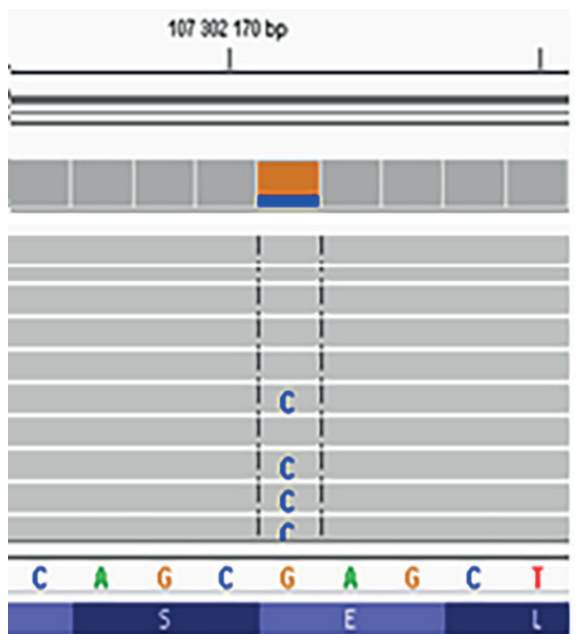

SLC26A4 e1

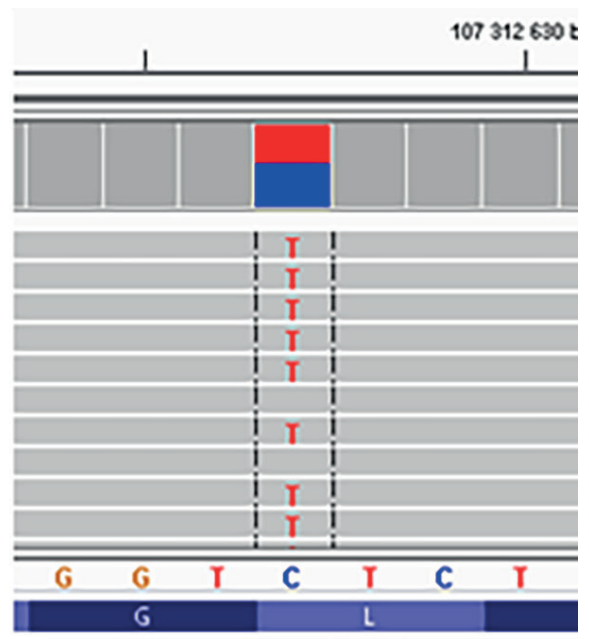

SLC26A4 e4

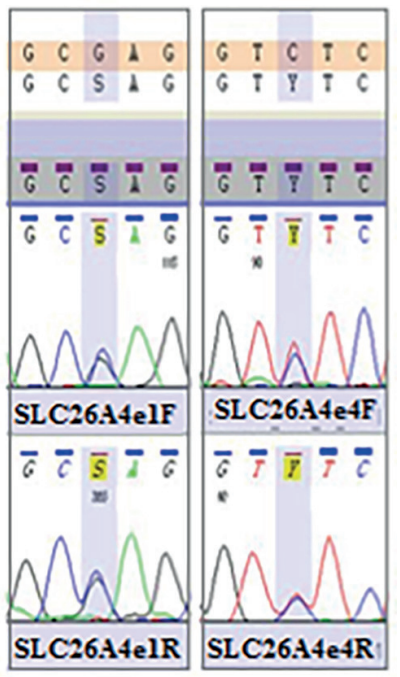



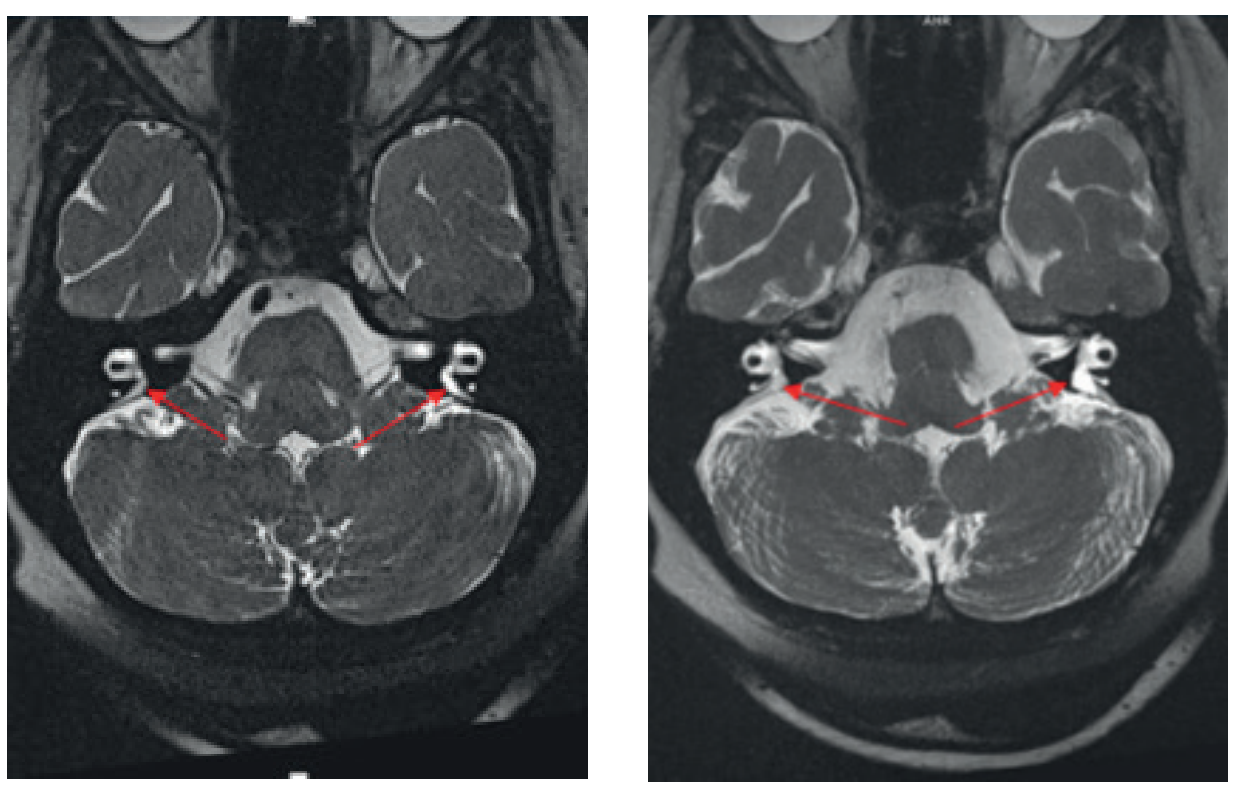

Rycina 4. Obraz badań wykonanych techniką rezonansu magnetycznego u pacjentki - obustronna malformacja typu IP2 (poszerzony wodociąg przedsionka (EVA) i dysplazja środkowo-szczytowych odcinków ślimaka)

Figure 4. Magnetic resonance examinations revealed bilateral inner ear malformation corresponding to incomplete partition type II (enlarged vestibular aqueduct (EVA) and dysplasia of mid-peak sections of the cochlea)

uwarunkowanego genetycznie, dziedziczonego w sposób autosomalny recesywny [32]. Należy podkreślić, że pacjenci z patogennymi wariantami w tym genie wykazują istotne zróżnicowanie obrazu fenotypowego - począwszy od pełnoobjawowego PDS, poprzez niedosłuch z malformacjami ucha wewnętrznego (EVA, EVA/MD) aż po izolowany niedosłuch zmysłowo-nerwowy (DFNB4). Najczęściej występującą manifestacją fenotypową patogennych wariantów genu SLC26A4 jest obustronne EVA lub EVA/ MD [33]. Poszerzony wodociąg przedsionka to wrodzona anomalia budowy ucha wewnętrznego, u podłoża której mogą leżeć patogenne warianty genu SLC26A4, lecz nie należy zapominać, iż obustronne EVA może być również efektem uszkodzenia innych genów, takich jak FOXI1 czy KCNJ10 [2,34].

W początkowych etapach diagnostyki molekularnej brano pod uwagę również możliwość współistniejącego defektu metabolicznego, ze względu na znaczące zaostrzanie się objawów po stresie i urazach oraz podwyższony poziom kwasu mlekowego. Obraz taki mógł sugerować chorobę mitochondrialną, jako dodatkową komponentę wyjaśniającą część objawów. Podobne przypadki współistnienia dwóch niezależnych chorób uwarunkowanych genetycznie opisywano w literaturze [35]. W badaniach molekularnych wykluczono obecność wariantu m.3243A > G sprawczego dla zespołu MELAS, w toku analizy całej sekwencji DNA mitochondrialnego zidentyfikowano wariant m.961T $>\mathrm{G}$ zlokalizowany w genie MT-RNR1 kodującym mitochondrialne $12 \mathrm{~S}$ rRNA. Jest to wariant, którego związek z niedosłuchem jest dyskusyjny [36,37], do tej pory nie został również powiązany z jakimikolwiek zaburzeniami metabolicznymi. Należy więc uznać go za znalezisko przypadkowe, niewyjaśniające podwyższonego poziomu kwasu mlekowego obserwowanego u pacjentki.

Dalsze poszukiwania molekularnej przyczyny niedosłuchu u przedstawianej pacjentki prowadzono $\mathrm{z}$ zastosowaniem WES umożliwiającego jednoczasową analizę wszystkich znanych ludzkich genów. Analiza wyników sekwencjonowania WES wykazała obecność dwóch wariantów w obszarze kodującym genu SLC26A4 zakwalifikowanych jako patogenne $[15,31]$ i powiązane $\mathrm{z}$ wystąpieniem niedosłuchu oraz malformacji ucha wewnętrznego (EVA, EVA/MD), należy więc je uznać za molekularną przyczynę niedosłuchu u pacjentki. Ponadto potwierdzono obecność ww. wariantów u niedosłyszącej siostry pacjentki. Analiza segregacji wykazała obecność heterozygotycznych wariantów u obojga rodziców badanych pacjentek - tym samym potwierdziła ich lokalizację na odrębnych chromosomach (układ in trans) (rycina 2).

Wariant c.85G $>$ C zlokalizowany jest w drugim eksonie kodującym genu SLC26A4 w wysoko konserwowanym regionie białka (rycina 5), w pierwszej domenie cytoplazmatycznej. Skutkuje zamianą kwasu glutaminowego na glutaminę w 29 pozycji aminokwasowej. W badaniach funkcjonalnych tego wariantu wykazano istotną redukcję poziomu transportu anionów $\mathrm{Cl}^{-1} \mathrm{i}$,

Rycina 5. Analiza konserwatywności aminokwasów Glu29 i Leu117 białka SLC26A4 u człowieka i innych gatunków kręgowców (wykonana z użyciem algorytmu Mutation Taster2)

Figure 5. Conservation of amino acids Glu29 and Leu117 of the SLC26A4 protein in human and other vertebrates

\begin{tabular}{|c|c|c|c|}
\hline species & match & gene & aa alignment \\
\hline Human & & & 29 C SYMVSRPVYSELAFQQQHERRLQ \\
\hline mutated & all conserved & & 29 C SYMVSRPVYS QLAFQQQHERRL \\
\hline Ptroglodytes & all identical & ENSPTRG08000019581 & 29 CSYVVSRPVYSELAFQQQHERRL \\
\hline $\begin{array}{l}\text { Mmulatta } \\
\text { Fcatus }\end{array}$ & $\begin{array}{l}\text { all identical } \\
\text { no homologue }\end{array}$ & ENSIMUG98000019125 & 29CSYVVSRPVYSELAFQQQHERRL \\
\hline Mnusculus & all identical & ENSIMSG60000020651 & 29 CSYTVSRPVYSELAFQQQRERRL \\
\hline Ggallus & all identical & ENSGAL G00000007998 & 28 - HYVVARPIYNEAGFQEENERLP \\
\hline Trubripes & no homologue & & \\
\hline \multirow[t]{2}{*}{ Drerio } & no homologue & & \\
\hline & & & p.Leu117Phe \\
\hline species & match & gene & aa alignment \\
\hline Human & & & 117 A LLAAVPVGYGLYSAFFPILTYFI \\
\hline mutated & not conserved & & 117 ALLAAVPVGYGFYSA \\
\hline Ptroglodytes & all identical & ENSPTRGQ00000019581 & 117 A LLAAVPVGYGLYSA \\
\hline Mmulatta & all identical & ENSMMUG00800019125 & 117 A L L A A VPVG YG LY S A \\
\hline Fcatus & no homologue & & \\
\hline Mmusculus & $\begin{array}{l}\text { all identical } \\
\text { all identical }\end{array}$ & 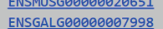 & $\begin{array}{l}117 \text { A LLA A VPVQF GLYSA } \\
114 \text { ALLLAVPVGYGLYSAFF }\end{array}$ \\
\hline $\begin{array}{l}\text { Ggallus } \\
\text { Trubripes }\end{array}$ & $\begin{array}{l}\text { all 1entical } \\
\text { no homologue }\end{array}$ & & \\
\hline Drerio & no homologue & & \\
\hline
\end{tabular}


lecz nie całkowity jego brak (jak w przypadku innych testowanych wariantów) - co może tłumaczyć brak nieprawidłowości ze strony tarczycy u pacjentek. Wariant c.85G >C został opisany jako współistniejący $\mathrm{z}$ wariantem p.Thr416Pro u pacjenta $\mathrm{z}$ niedosłuchem $\mathrm{w}$ stopniu lekkim do ciężkiego (krzywa audiologiczna opadająca), obustronnym EVA i małymi małżowinami usznymi [31]. W innym opisywanym przypadku pacjenta $\mathrm{z}$ wariantem c.85G $>\mathrm{C}$ również odnotowano obustronny niedosłuch i EVA bez niedoczynności tarczycy, nie wykryto jednak drugiego wariantu patogennego w genie SLC26A4, więc w tej szczególnej sytuacji związek wariantu c.85G $>C$ z fenotypem pacjenta nie jest jasny [38]. Z uwagi na udokumentowane przypadki dwugenowego dziedziczenia u pacjentów z EVA lub EVA/MD u osób z pojedynczym wariantem patogennym w genie SLC26A4 należy poszerzyć badania molekularne o analizę genów FOXI1 i KCNJ10. W badaniach na modelu mysim wykazano, że gen Foxil jest czynnikiem transkrypcyjnym dla genu Slc26a4 [2, 39], a u myszy z niefunkcjonalnym genem Foxil nie obserwuje się transkrypcji Slc26a4. Opisano również pacjentów z heterozygotycznymi wariantami genów SLC26A4 i FOXI1 i objawami DFNB4. Produkt białkowy genu KCNJ10 to kanał potasowy [34], a warianty patogenne w tym genie obniżają zdolność przewodnictwa jonów potasu, a tym samym wpływają negatywnie na potencjał wewnątrzślimakowy. Ponadto haploinsuficjencja Slc26a4 u myszy powoduje obniżenie poziomu ekspresji białka Kcnj10 w uchu wewnętrznym. Tak ścisłe współdziałanie obu tych genów potwierdzają również przypadki pacjentów $\mathrm{z}$ wariantami heterozygotycznymi w tych genach skutkującymi niedosłuchem i EVA [34]. W opisywanym w pracy przypadku zidentyfikowano dwa warianty patogenne w genie SLC26A4, dodatkowych wariantów patogennych w genach FOXI1 i KCNJ10 nie znaleziono - potwierdzając tym samym monogenową przyczynę występujących objawów.

Wariant c.349C $>$ T zlokalizowany jest w obrębie eksonu 4 kodującego genu SLC26A4, w pierwszej domenie przezbłonowej. Jego bezpośrednim efektem białkowym jest zamiana wysoce konserwowanej leucyny w pozycji $117 \mathrm{w}$ fenyloalaninę (rycina 5). W badaniach funkcjonalnych tego wariantu nie wykazano jego negatywnego wpływu na poziom transportu jonów I' do komórek, lokalizacja białka również była prawidłowa. Nie badano wpływu wariantu c.349C > T na poziom transportu jonów $\mathrm{Cl}^{-}$. Dane literaturowe opisują pacjenta $\mathrm{z}$ niedosłuchem i EVA, lecz bez objawów dysfunkcji tarczycy, u którego zidentyfikowano ten wariant w postaci heterozygotycznej (bez wariantu komplementującego) [40].

Podsumowując, nie opisano $\mathrm{w}$ literaturze pacjenta $\mathrm{z}$ genotypem identycznym jak wykryty u badanej pacjentki, aczkolwiek oba warianty analizowane niezależnie nie są

\section{Piśmiennictwo:}

1. Nance WE. The genetics of deafness. Ment Retard Dev Disabil Res Rev, 2003; 9(2): 109-19.

2. Yang T, Vidarsson H, Rodrigo-Blomqvist S, Rosengren SS, Enerback S, Smith RJ. Transcriptional control of SLC26A4 is involved in Pendred syndrome and nonsyndromic enlargement of vestibular aqueduct (DFNB4). Am J Hum Genet, 2007; 80(6): 1055-63. powiązane $\mathrm{z}$ fenotypem tarczycowym. Dane literaturowe sugerują również, że w krajach o wysokim spożyciu jodu rozwój wola i dysfunkcji tarczycy zwykle nie występuje u pacjentów z biallelicznymi wariantami genu SLC26A4 [41]. Polska należy do nielicznych krajów Europy, które wprowadziły skuteczny, obligatoryjny model jodowania soli kuchennej [42], co może również tłumaczyć brak dysfunkcji tarczycy u opisywanych pacjentek.

U przedstawianej pacjentki oraz jej siostry odnotowano istotnie mniejszy w stosunku do normy rozmiar małżowin usznych. Takie dyskretne cechy dysmorficzne występują, choć rzadko, u pacjentów z patogennymi wariantami w genie SLC26A4 [43], nie są one jednak cechą charakterystyczną dla spektrum PDS/DFNB4. Do tej pory nie opisano w literaturze u pacjentów PDS/DFNB4 wąskich przewodów słuchowych, co w przypadku przedstawianej rodziny może być cechą osobniczą, powiązaną ze zmniejszonym rozmiarem małżowin usznych.

U pacjentów z EVA niedosłuch postępuje zwykle w sposób skokowy, uważa się, że mechanizmem inicjującym epizody pogarszania stanu słuchu są nagłe i szybkie zmiany ciśnienia (np. podczas lotów samolotem czy nurkowania), urazy głowy czy też znaczny wysiłek fizyczny. Za przyczynę epizodów pogorszenia słuchu uznaje się niszczący efekt przeniesienia ciśnienia płynu mózgowo-rdzeniowego do przestrzeni ucha wewnętrznego [44], choć teoria ta nie została w sposób jednoznaczny potwierdzona. Na podstawie aktualnego stanu wiedzy należy więc uznać, że przyczyną występowania epizodów pogorszenia słuchu jest EVA i uszkodzenie genu SLC26A4.

\section{Wnioski}

Zastosowanie technologii sekwencjonowania nowej generacji umożliwiło detekcję wariantów sprawczych u pacjentki z epizodycznie postępującym niedosłuchem, EVA oraz dysplazją środkowo-szczytowych odcinków ślimaka. Wczesne i precyzyjne postawienie rozpoznania w przypadku opisywanego schorzenia jest niezwykle istotne, gdyż pozwala na wdrożenie postępowania prewencyjnego w postaci unikania urazów głowy oraz sytuacji, w których dochodzi do gwałtownych zmian ciśnienia, takich jak loty samolotem, komora hiperbaryczna czy nurkowanie. U pacjentów z rodzinnym niedosłuchem i nagłymi epizodami pogorszenia słuchu należy rozważyć analizę genu SLC26A.

Publikacja powstała w związku z realizacją projektów: Grant NCN: 2011/03/D/NZ5/05592, Grant NCN: 2012/05/N/NZ5/02629 oraz projektów statutowych IFPS.
3. Kalatzis V, Petit C. The fundamental and medical impacts of recent progress in research on hereditary hearing loss. Hum Mol Genet, 1998; 7(10): 1589-97.

4. Gettelfinger JD, Dahl JP. Syndromic Hearing Loss: A Brief Review of Common Presentations and Genetics. J Pediatr Genet, 2018; 7(1): 1-8.

5. Reardon W, Coffey R, Phelps PD, Luxon LM, Stephens D, Kendall-Taylor P i wsp. Pendred syndrome - 100 years of underascertainment? QJM, 1997; 90(7): 443-47. 
6. Fraser GR. Association of Congenital Deafness with Goitre (Pendred's Syndrome) a Study of 207 Families. Ann Hum Genet, 1965; 28: 201-49.

7. Everett LA, Glaser B, Beck JC, Idol JR, Buchs A, Heyman M, i wsp. Pendred syndrome is caused by mutations in a putative sulphate transporter gene (PDS). Nat Genet, 1997; 17(4): 411-22.

8. Choi BY, Kim HM, Ito T, Lee KY, Li X, Monahan K, i wsp. Mouse model of enlarged vestibular aqueducts defines temporal requirement of Slc26a4 expression for hearing acquisition. J Clin Invest, 2011; 121(11): 4516-25.

9. Wangemann P, Nakaya K, Wu T, Maganti RJ, Itza EM, Sanneman JD, i wsp. Loss of cochlear HCO3- secretion causes deafness via endolymphatic acidification and inhibition of $\mathrm{Ca} 2+\mathrm{re}-$ absorption in a Pendred syndrome mouse model. Am J Physiol Renal Physiol, 2007; 292(5): 1345-53.

10. Yoshida A, Taniguchi S, Hisatome I, Royaux IE, Green ED, Kohn LD, i wsp. Pendrin is an iodide-specific apical porter responsible for iodide efflux from thyroid cells. J Clin Endocrinol Metab, 2002; 87(7): 3356-61.

11. Royaux IE, Wall SM, Karniski LP, Everett LA, Suzuki K, Knepper MA, i wsp. Pendrin, encoded by the Pendred syndrome gene, resides in the apical region of renal intercalated cells and mediates bicarbonate secretion. Proc Natl Acad Sci U S A, 2001; 98(7): 4221-26.

12. Everett LA, Morsli H, Wu DK, Green ED. Expression pattern of the mouse ortholog of the Pendred's syndrome gene (Pds) suggests a key role for pendrin in the inner ear. Proc Natl Acad Sci U S A, 1999; 96(17): 9727-32.

13. Scott DA, Wang R, Kreman TM, Sheffield VC, Karniski LP. The Pendred syndrome gene encodes a chloride-iodide transport protein. Nat Genet, 1999; 21(4): 440-43.

14. Phelps PD, Coffey RA, Trembath RC, Luxon LM, Grossman AB, Britton KE, i wsp. Radiological malformations of the ear in Pendred syndrome. Clin Radiol, 1998; 53(4): 268-73.

15. Reardon W, CF OM, Trembath R, Jan H, Phelps PD. Enlarged vestibular aqueduct: a radiological marker of pendred syndrome, and mutation of the PDS gene. QJM, 2000; 93(2): 99-104.

16. Valvassori GE, Clemis JD. The large vestibular aqueduct syndrome. Laryngoscope, 1978; 88(5): 723-28.

17. Furmanek MI, Piotrowska A, Skarżyński H, Bogusławska-Walecka R, Walecki J. Wartość wielorzędowej tomografii komputerowej w wykrywaniu wad wrodzonych ucha wewnętrznego oraz przydatność metody w klinicznej kwalifikacji do implantacji. Otolaryngologia Polska, 2007; 61(4): 585-90.

18. Smith R. Pendred Syndrome/Nonsyndromic Enlarged Vestibular Aqueduct Seattle (WA): University of Washington, Seattle; 1993-20181998 Sep 28 [Updated 2017 Oct 19] [

19. Koffler T, Ushakov K, Avraham KB. Genetics of Hearing Loss: Syndromic. Otolaryngol Clin North Am, 2015; 48(6): 1041-61.

20. Roesch S, Bernardinelli E, Nofziger C, Toth M, Patsch W, Rasp G, i wsp. Functional Testing of SLC26A4 Variants-Clinical and Molecular Analysis of a Cohort with Enlarged Vestibular Aqueduct from Austria. Int J Mol Sci, 2018; 19(1).

21. Tsukada K, Nishio S-y, Hattori M, Usami S-i. Ethnic-specific spectrum of GJB2 and SLC26A4 mutations: their origin and a literature review. Annals of Otology, Rhinology \& Laryngology, 2015; 124(1_suppl): 61-76.

22. Gripp KW, Slavotinek AM, Allanson JE. Handbook of physical measurements: Oxford University Press; 2013.

23. Olszewski Ł, Jedrzejczak WW, Sliwa L, Fabijanska A, Skarzynski $\mathrm{H}$. Use of wideband absorbance measurement to assess large Vestibular Aqueduct Syndrome: A case study. Journal of Hearing Science, 2017; 7(1).
24. Miller SA, Dykes DD, Polesky HF. A simple salting out procedure for extracting DNA from human nucleated cells. Nucleic Acids Res, 1988; 16(3): 1215.

25. Pollak A, Skarzynski H. Prevalence of DFNB1 hearing loss among cochlear implant users established with the b-step DFNB1 approach. Journal of Hearing Science, 2017; 7(1).

26. Iwanicka-Pronicka K, Pollak A, Skorka A, Lechowicz U, Korniszewski L, Westfal P i wsp. Audio profiles in mitochondrial deafness $\mathrm{m} .1555 \mathrm{~A}>\mathrm{G}$ and $\mathrm{m} .3243 \mathrm{~A}>\mathrm{G}$ show distinct differences. Med Sci Monit, 2015; 21: 694-700.

27. Iwanicka-Pronicka K, Pollak A, Skorka A, Lechowicz U, Pajdowska M, Furmanek M i wsp. Postlingual hearing loss as a mitochondrial 3243A $>$ G mutation phenotype. PLoS One, 2012; 7(10): 44054.

28. Ploski R, Pollak A, Muller S, Franaszczyk M, Michalak E, Kosinska J i wsp. Does p.Q247X in TRIM63 cause human hypertrophic cardiomyopathy? Circ Res, 2014; 114(2): 2-5.

29. Schwarz JM, Cooper DN, Schuelke M, Seelow D. MutationTaster2: mutation prediction for the deep-sequencing age. Nat Methods, 2014; 11(4): 361-62.

30. Lechowicz U, Stawiński P, Mueller-Malesińska M, Płoski R. Genetycznie uwarunkowany niedosłuch - perspektywy i możliwości diagnostyczne z wykorzystaniem sekwencjonowania nowej generacji. Now Audiofonol, 2013; 2(4).

31. Campbell C, Cucci RA, Prasad S, Green GE, Edeal JB, Galer CE i wsp. Pendred syndrome, DFNB4, and PDS/SLC26A4 identification of eight novel mutations and possible genotype-phenotype correlations. Hum Mutat, 2001; 17(5): 403-11.

32. Sloan-Heggen CM, Bierer AO, Shearer AE, Kolbe DL, Nishimura CJ, Frees KL i wsp. Comprehensive genetic testing in the clinical evaluation of 1119 patients with hearing loss. Hum Genet, 2016; 135(4): 441-50.

33. Pourova R, Janousek P, Jurovcik M, Dvorakova M, Malikova M, Raskova D i wsp. Spectrum and frequency of SLC26A4 mutations among Czech patients with early hearing loss with and without Enlarged Vestibular Aqueduct (EVA). Ann Hum Genet, 2010; 74(4): 299-307.

34. Yang T, Gurrola JG, 2nd, Wu H, Chiu SM, Wangemann P, Snyder PM, i wsp. Mutations of KCNJ10 together with mutations of SLC26A4 cause digenic nonsyndromic hearing loss associated with enlarged vestibular aqueduct syndrome. Am J Hum Genet, 2009; 84(5): 651-57.

35. Kalinska-Bienias A, Pollak A, Kowalewski C, Lechowicz U, Stawinski $\mathrm{P}$, Gergont A, i wsp. Coexistence of mutations in keratin 10 (KRT10) and the mitochondrial genome in a patient with ichthyosis with confetti and Leber's hereditary optic neuropathy. Am J Med Genet A, 2017; 173(11): 3093-97.

36. Elstner M, Schmidt C, Zingler VC, Prokisch H, Bettecken T, Elson JL, i wsp. Mitochondrial 12S rRNA susceptibility mutations in aminoglycoside-associated and idiopathic bilateral vestibulopathy. Biochem Biophys Res Commun, 2008; 377(2): 379-83.

37. Li R, Greinwald JH, Yang L, Choo DI, Wenstrup RJ, Guan MX. Molecular analysis of the mitochondrial 12S rRNA and tRNASer(UCN) genes in paediatric subjects with non-syndromic hearing loss. J Med Genet, 2004; 41(8): 615-20.

38. Ladsous M, Vlaeminck-Guillem V, Dumur V, Vincent C, Dubrulle F, Dhaenens CM i wsp. Analysis of the thyroid phenotype in 42 patients with Pendred syndrome and nonsyndromic enlargement of the vestibular aqueduct. Thyroid, 2014; 24(4): $639-48$. 
39. Hulander M, Kiernan AE, Blomqvist SR, Carlsson P, Samuelsson EJ, Johansson BR i wsp. Lack of pendrin expression leads to deafness and expansion of the endolymphatic compartment in inner ears of Foxil null mutant mice. Development, 2003; 130(9): 2013-25.

40. Taylor JP, Metcalfe RA, Watson PF, Weetman AP, Trembath RC. Mutations of the PDS gene, encoding pendrin, are associated with protein mislocalization and loss of iodide efflux: implications for thyroid dysfunction in Pendred syndrome. J Clin Endocrinol Metab, 2002; 87(4): 1778-84.

41. Kopp P. Mutations in the Pendred syndrome (PDS/SLC26A) gene: an increasingly complex phenotypic spectrum from goiter to thyroid hypoplasia. J Clin Endocrinol Metab, 2014; 99(1): 67-69.
42. Szybiński Z. Sytuacja profilaktyki jodowej w Polsce w świetle ostatnich rekomendacji WHO dotyczących ograniczenia spożycia soli. Pediatric Endocrinology, Diabetes \& Metabolism, 2009; 15(2).

43. Campbell C, Cucci RA, Prasad S, Green GE, Edeal JB, Galer CE i wsp. Pendred syndrome, DFNB4, and PDS/SLC26A4 identification of eight novel mutations and possible genotype-phenotype correlations. Human mutation, 2001; 17(5): 403-11.

44. Żarowski A, Skarżyński H, Skarżyńska B, Miszka K. Skokowo postępowy niedosłuch spowodowany poszerzeniem wodąciągu przedsionka - Large Vestibular Aqueduct Syndrome (LVAS). Audiofonologia, 2000; 18: 187-194. 